\title{
Beltraniopsis rhombispora and Hemibeltrania decorosa from leaf litter in the Atlantic Forest in southern Bahia, Brazil
}

\author{
Marcos Vinícius Oliveira dos Santos ${ }^{1,3,5}$, Flávia Rodrigues Barbosa ${ }^{2}$, Edna Dora Martins Newman Luz ${ }^{3}$ \\ \& José Luiz Bezerra ${ }^{1,4}$
}

\begin{abstract}
Species of the Beltrania group are constantly identified in association with a variety of plant debris in Brazil and different localities of the world. Leaf litter samples of Myrcia splendens and Pera glabrata were collected in the Reserva Biológica de Una, municipality of Una, Bahia state, Brazil, in August 2012, and incubated in moist chambers. Two specimens related to Beltrania group were isolated and identified by morphological criteria. This study aimed to describe and illustrate Beltraniopsis rhombispora for the first time in Brazil. Hemibeltrania decorosa previously reported from Caatinga Biome, Bahia state, has been cited for the first time for Atlantic Forest.

Key words: Beltrania group, conidial fungi, diversity, hyphomycetes, taxonomy.

Resumo

Espécies do grupo Beltrania são constantemente identificadas em associação com uma variedade de substratos vegetais em decomposição no Brasil e em diferentes localidades do mundo. Amostras de folhedo de Myrcia splendens e Pera glabrata foram coletadas na Reserva Biológica de Una, município de Una, estado da Bahia, Brasil, em agosto de 2012, e incubadas em câmara úmida. Dois espécimes relacionados ao grupo Beltrania foram isolados e identificados por critérios morfológicos. Este estudo objetivou descrever e ilustrar Beltraniopsis rhombispora pela primeira vez no Brasil. Hemibeltrania decorosa, anteriormente, reportada no bioma Caatinga, estado da Bahia, está sendo citada pela primeira vez na Mata Atlântica.

Palavras-chave: grupo Beltrania, fungos conidiais, diversidade, hifomicetos, taxonomia.
\end{abstract}

\section{Introduction}

The tribe Beltraniae (Family Dematieae later Dematiaceae) was created in 1886 by Saccardo to accommodate the genus Beltrania Penz. and two species: B. rhombica Penz. and B. querna Harkn. Beltraniae differs from other tribes of the Didymosporae group in having setae mixed with conidiophores and by presence of rostrated acrogenous conidia (Saccardo 1886; Pirozynski 1963).

Pirozynski (1963), at that time, in a review of some genera, showed that Beltrania, Beltraniella Subram., Ellisiopsis Bat., Beltraniopsis Bat. \& J.L. Bezerra, Pseudobeltrania Henn. and Hemibeltrania
Piroz. (except Rhombostilbella Zimm.) formed a natural group. The author considered the following as taxonomically important characters: internal mycelium, stroma, superficial mycelium, setae and conidiophores, as well as separating cells and conidia.

Kendrick (1980), presented proposals for condensation of genera, and established that representative members of the Beltrania group should have, at least, three of the following: 1) dark setae; 2 ) setae or conidiophores with radially lobed basal cell; 3) cell separation; 4) biconical conidia; 5) conidia with a hyaline equatorial band. Thus, only genera Beltrania, Beltraniopsis,

\footnotetext{
${ }^{1}$ Universidade Federal de Pernambuco, Depto. Micologia, Av. Prof. Nelson Chaves s/n, 50670-901, Recife, PE, Brasil.

${ }^{2}$ Universidade Federal de Mato Grosso, Inst. Ciências Naturais, Humanas e Sociais, Av. Alexandre Ferronato 1200, Setor Industrial, 78557-267, Sinop, MT, Brasil.

${ }^{3}$ Centro de Pesquisas do Cacau, Setor de Fitopatologia, Comissão Executiva do Plano da Lavoura Cacaueira, Rod. Ilhéus-Itabuna Km 22, 45662-000, Ilhéus, BA, Brasil.

${ }^{4}$ Universidade Federal do Recôncavo da Bahia, Centro de Ciências Agrárias e Biológicas, R. Rui Barbosa 710, 44380-000, Cruz das Almas, BA, Brasil.

${ }^{5}$ Author for correspondence: marcosvos@ymail.com
} 
Beltraniella, Ellisiopsis and Pseudobeltrania would remain in Beltrania group. Nowadays, Ellisiopsis is considered synonymous with Beltraniella (Seifert et al. 2011). Hemibeltrania and Rhombostilbella would be excluded to have only one of the five listed characteristics. In recent years, new genera (Porobeltraniella Gusmão and Maxibeltrania Rambelli) and new species (Beltrania pseudorhombica Crous \& Y. Zhang ter, Beltraniella endiandrae Crous \& Summerell and Beltraniopsis neolitseae Crous \& Summerell.) were included in Beltrania group (Gusmão 2004; Rambelli 2011; Crous et al. 2014a,b,c). It is evident that researches should be realized to elucidate several aspects, such as the taxa excluded and the new genera found.

Species of Beltrania group are commonly reported in diversity and fungal succession studies (Maia 1983; Rambelli 2011; Shanthi \& Vittal 2012, and others). In Brazil there are constant reports of taxa in the Beltrania group (Gusmão et al. 2001; Barbosa et al. 2009; Almeida et al. 2011; Castro et al. 2012; Magalhães et al. 2013, and others). In specific studies within this group in the Paraná state, Gusmão \& Grandi (1996) cataloged five species associated with leaf litter and/or live leaves of Cedrela fissilis Vell., and reported two new records to Brazil.

In the southern region of Bahia state only four species of Beltrania group have been recorded, such as: Beltrania rhombica, $B$. querna, Beltraniella portoricensis (F. Stevens) Piroz. \& S.D. Patil (Magalhães et al. 2013) and Beltraniella botryospora Shirouzu \& Tokum. (Santos et al. 2014). This study aimed to describe and illustrate Beltraniopsis rhombispora for the first time in Brazil and to report the first record of Hemibeltrania decorosa for Atlantic Forest.

\section{Materials and Methods}

Collecting expedition was undertaken on August 2012 to the Reserva Biológica de Una $\left(15^{\circ} 10.630^{\prime} \mathrm{S}\right.$ and $\left.39^{\circ} 03.478^{\prime} \mathrm{W}\right)$, municipality of Una, Bahia state, Brazil. Leaf litter was collected from 10 plants: five from Myrcia splendens (Sw.) DC. (Myrtaceae) and five from Pera glabrata (Schott) Poepp. ex Baill. (Peraceae). The samples were stored in Kraft paper bags and sent to the laboratório de Diversidade de Fungos of the Centro de Pesquisas do Cacau (Cepec), Comissão Executiva do Plano da Lavoura Cacaueira (Ceplac), Ilhéus, Bahia.
In the laboratory, samples were washed for one hour in running water and incubated at $25^{\circ} \mathrm{C}$ in moist chambers (Castañeda Ruiz et al. 2006a, with modifications). The samples were examined at regular intervals for the presence of conidial fungi. Reproductive structures were located on the substrates with a dissecting microscope and removed to a glass slide where they were mounted in polyvinyl alcohol, lactic acid and glycerol (PVLG) resin (Silva \& Grandi 2011). Morphological characters were used to identify species (Ellis 1971; Castañeda Ruiz \& Kendrick 1991; Matsushima 1993; Seifert et al. 2011) and the permanent slides were deposited in Herbarium CEPEC. Pictures of fungi were obtained using DP25 camera attached to the microscope with Imaging Software Cellsens - 2.3 version, build 7045 and Combine ZP 1.0 version.

\section{Results and Discussion}

1. Beltraniopsis rhombispora Matsush., Matsushima Mycological Memoirs 7: 44 (1993).

Fig. 1

Setae absent. Conidiophores macronematous, mononematous, setiform, single, branched or not, smooth-walled, erect to slightly flexuous, septate, arising from lobated basal cell, brown to subhyaline towards the apex, apical cell slightly inflated, 69.6-204 tall, 4-6.4 $\mu \mathrm{m}$ wide at the base. Conidiogenous cells polyblastic, discrete, sympodial, lateral and intercalate, denticulate, pale brown, 5.4-9.4 × 4-5.6 $\mu \mathrm{m}$. Separating cells

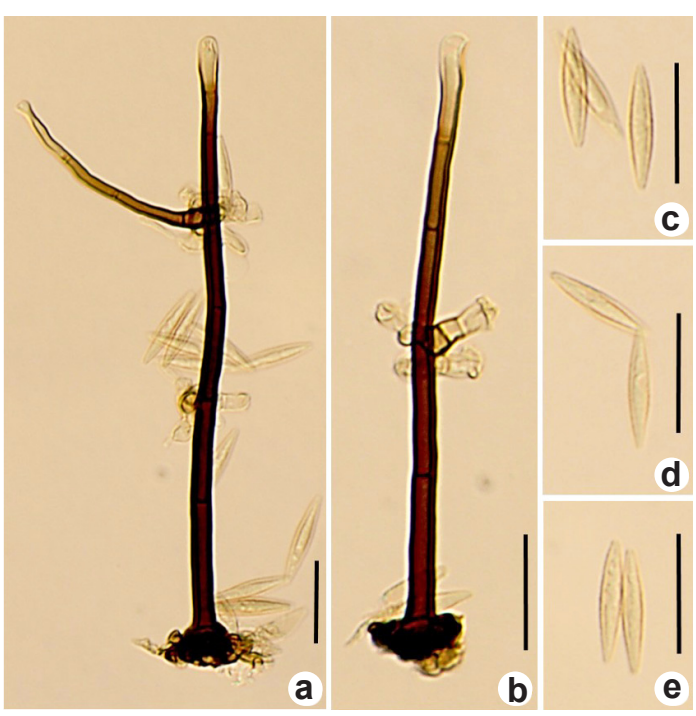

Figure 1 - Beltraniopsis rhombispora - a-b. conidiophores; c-e. conidia. Scale bars: a-e $=20 \mu \mathrm{m}$. 
absent. Conidia solitary, smooth, simple, biconic, 0 -septate, not rostrate, transverse band absent, pale olivaceo, $18.6-22 \times 3.4-4.2 \mu \mathrm{m}$.

Material examined: Una, 26.VIII.2012, on decomposing leaves of Pera glabrata, M.V.O. dos Santos 26 (CEPEC 2442).

Geographical distribution: Peru (Matsushima 1993), Brazil (this paper).

Comments: The examined material has setiforms conidiophores bigger and wider (70-130 $\times$ $3.5-5 \mu \mathrm{m})$ and conidia bigger [12-(15-21) $\mu \mathrm{m}]$ than those in the original description (Matsushima 1993).

Beltraniopsis rhombispora is similar to $B$. aquatica R.F. Castañeda \& M. Stadler by having lateral conidiogenous cells, conidia without rostrum and transverse band and separating cells absent. However, B. aquatica has conidiophore with inflated basal cell, and conidia brown, fusiform to navicular, slightly constricted in the middle region, smooth or minimally verruculose (Castañeda Ruiz et al. 2006b).

Currently, the genus has nine species (Batista \& Bezerra 1960; Matsushima 1971; 1993; Pirozynski 1972; Castañeda Ruiz \& Arnold 1985; Rambelli \& Ciccarone 1985; Gusmão et al. 2000; CastañedaRuiz et al. 2006b; Crous et al. 2014b). Beltraniopsis esenbeckiae Bat. \& J.L. Bezerra (Batista \& Bezerra 1960) and B. miconiae Gusmão \& Grandi (Gusmão et al. 2000) have been described in Brazil, and $B$. ramosa R.F. Castañeda has previously been found in Brazil (Gusmão \& Grandi 1996). This is the second record of $B$. rhombispora in the world and the first record of this species in Brazil on Pera glabrata leaf litter.

2. Hemibeltrania decorosa R.F. Castañeda \& W.B. Kendr., Univ. Waterloo Biol. Ser. 35: 57 (1991)

Descriptions and illustrations: Castañeda Ruiz \& Kendrick (1991); Almeida et al. (2011).

Material examined: Una, 26.VIII.2012, on decomposing leaves of Myrcia splendens, M.V.O. dos Santos 18 (CEPEC 2434).

Geographical distribution: Cuba (Castañeda Ruiz \& Kendrick 1991), Mauritius (Dulymamode et al. 2001) and Brazil (Almeida et al. 2011).

Comments: The first record of this species in Brazil was on leaf litter of an unidentified dicotyledonous in Caatinga Biome, Bahia state (Almeida et al. 2011). The examined material has conidiophores bigger and wider than those in the description presented by Almeida et al. (2011). Hemibeltrania decorosa is distinguished from other species of the genus, especially $H$. saikawae and $H$. cymbiformis, by morphology and peculiarities of the conidiophores and conidia, respectively.
Hemibeltrania decorosa was initially reported in Cuba on leaf litter of Myrica cerifera $\mathrm{L}$. (Myricaceae) (Castañeda Ruiz \& Kendrick 1991). This is the first report of the species in the Atlantic Forest and on Myrcia splendens leaf litter.

\section{Acknowledgements}

The authors wish to thank the Coordenação de Aperfeiçoamento de Pessoal de Nível Superior (CAPES) and the Conselho Nacional de Desenvolvimento Científico e Tecnológico (CNPq), for fellowships awarded to the first and to the last two authors, respectively. We would also like to thank to Dr. Luís Fernando Pascholati Gusmão and José Lima da Paixão, the Centro de Pesquisas do Cacau (CEPEC), the ICMBio, the REBIO-Una and the Programa de Pós-graduação em Biologia de Fungos of the Universidade Federal de Pernambuco (UFPE), for logistical support to this research.

\section{References}

Almeida, D.A.C.; Santa Izabel, T.S. \& Gusmão, L.F.P. 2011. Fungos conidiais do bioma Caatinga I. Novos registros para o continente americano, Neotrópico, América do Sul e Brasil. Rodriguésia 62: 43-53.

Barbosa, F.R.; Maia, L.C. \& Gusmão, L.F.P. 2009. Fungos conidiais associados ao folhedo de Clusia melchiorii Gleason e C. nemorosa G. Mey. (Clusiaceae) em fragmento de Mata Atlântica, BA, Brasil. Acta Botanica Brasilica 23: 79-84.

Batista, A.C. \& Bezerra, J.L. 1960. Beltraniopsis - novo gênero de fungos dematiaceae. Publicações do Instituto de Micologia da Universidade do Recife 296: 1-13.

Castañeda Ruiz, R.F. \& Arnold, G.R.W. 1985. Deuteromycotina de Cuba. I. Hyphomycetes. Revista del Jardín Botánico Nacional 6: 47-67.

Castañeda Ruiz, R.F. \& Kendrick, W.B. 1991. Ninetynine conidial fungi from Cuba and three from Canada. University of Waterloo, Biology Series 35: 1-132.

Castañeda Ruiz, R.F.; Gusmão, L.F.P.; Abarca, G.H. \& Saikawa, M. 2006a. Some hyphomycetes from Brazil. Two new species of Brachydesmiella, two new combinations for Repetophragma, and new records. Mycotaxon 95: 261-270.

Castañeda Ruiz, R.F.; Minter, D.W.; Stadler, M.; Saikawa, M. \& Camino-Vilaró, M. 2006b. Anamorphic fungi from submerged leaves in Cuba: Brevicatenospora enteroproliferata gen. et sp. nov. and Beltraniopsis aquatica sp. nov. Mycotaxon 96: 151-158.

Castro, C.C.; Gutiérrez, A.H. \& Sotão, H.M.P. 2012. Fungos conidiais em Euterpe oleracea Mart. (açaizeiro) na Ilha do Combu, Pará-Brasil. Acta Botanica Brasilica 26: 761-771.

Crous, P.W.; Groenewald, J.Z. \& Summerell, B.A. 2014a. Beltraniella endiandrae Crous \& Summerell, sp. nov. Persoonia 32: 210-211. 
Crous, P.W.; Groenewald, J.Z. \& Summerell, B.A. 2014b. Beltraniopsis neolitseae Crous \& Summerell, sp. nov. Persoonia 32: 208-209.

Crous, P.W.; Groenewald, J.Z. \& Zhang, Y. 2014c. Beltrania pseudorhombica Crous \& Y. Zhang ter, sp. nov. Persoonia 32: 266-267.

Dulymamode, R.; Cannon, P.F. \& Peerally, A. 2001. Fungi on endemic plants of Mauritius. Mycological Research 105: 1472-1479.

Ellis, M.B. 1971. Dematiaceous hyphomycetes. Commonwealth Mycological Institute, Kew. 608p.

Kendrick, B. 1980. The generic concept in hyphomycetes - A reappraisal. Mycotaxon 11: 339-364.

Gusmão, L.F.P. 2004. Porobeltraniella gen. nov. to accommodate two species of Beltraniella. Mycologia 96: 150-153.

Gusmão, L.F.P. \& Grandi, R.A.P. 1996. Espécies do grupo Beltrania (hyphomycetes) associadas a folhas de Cedrela fissilis Vell. (Meliaceae) em Maringá, PR, Brasil. Hoehnea 23: 91-102.

Gusmão, L.F.P.; Grandi, R.A.P. \& Milanez, A.I. 2000. A new species of Beltraniopsis from Brazil, with a key to the known species. Mycological Research 104: 251-253.

Gusmão, L.F.P.; Grandi, R.A.P. \& Milanez, A.I. 2001. Hyphomycetes from leaf litter of Miconia cabussu in the Brazilian Atlantic rain forest. Mycotaxon 79: 201-213.

Magalhães, D.M.A.; Luz, E.D.M.N.; Magalhães, A.F.; Santos, M.V.O. \& Bezerra, J.L. 2013. Fungos conidiais em plantas endêmicas da Mata Atlântica: novos registros para a Bahia. Agrotrópica 25: 109-116.

Maia, L.C. 1983. Sucessão de fungos em folhedo de floresta tropical úmida. Editora Universitária,
Universidade Federal de Pernambuco, Recife. 196p.

Matsushima, T. 1971. Microfungi of the Solomon Islands and Papua-New Guinea. Published by the author, Kobe. 78 p.

Matsushima, T. 1993. Matsushima Mycological Memoirs 7. Matsushima Mycological Memoirs 7: 1-141.

Pirozynski, K.A. 1963. Beltrania and related genera. Mycological Papers 90: 1-37.

Pirozynski, K.A. 1972. Microfungi of Tanzania. Mycological Papers 129: 1-64.

Rambelli, A. 2011. Some dematiaceous hyphomycetes from Mediterranean maquis litters. Flora Mediterranea 21: 5-204.

Rambelli, A. \& Ciccarone, C. 1985. Two new dematiaceous hyphomycetes from humid tropic forest litter. Giornale Botanico Italiano 119: 291294.

Saccardo, P.A. 1886. Sylloge Hyphomycetum. Sylloge Fungorum 4: 1-807.

Santos, M.V.O.; Barbosa, F.R.; Magalhães, D.M.A.; Luz, E.D.M.N. \& Bezerra, J.L. 2014. Beltraniella species associated with leaf litter of the Atlantic Forest in southern Bahia, Brazil. Mycotaxon 129: $1-6$.

Seifert, K.; Morgan-Jones, G.; Gams, W. \& Kendrick, B. 2011. The genera of hyphomycetes. CBS Biodiversity Series 9. CBS-KNAW Fungal Biodiversity Centre, Utrecht. 997p.

Shanthi, S. \& Vittal, B.P.R. 2012. Fungal diversity and the pattern of fungal colonization of Anacardium occidentale leaf litter. Mycology 3: 132-146.

Silva, P. \& Grandi, R.A.P. 2011. A new species of Thozetella (anamorphic fungi) from Brazil. Cryptogamie, Mycologie 32: 359-363. 